\title{
INFLUENCE OF PARENTAL FORMS ON CHANGES IN THE CONTENT OF MINERAL ELEMENTS IN GRAIN OF NEW WINTER TRITICALE HYBRID STRAINS
}

\author{
Ewa Makarska1 ${ }^{1}$, Anna Ciołek ${ }^{1}$, Wanda Kociuba ${ }^{2}$
}

\author{
${ }^{1}$ Chair of Chemistry \\ 2Plant Breeding and Biotechnology \\ University of Live Sciences in Lublin
}

\begin{abstract}
The paper presents a study on the content of $\mathrm{Ca}, \mathrm{Mg}, \mathrm{K}, \mathrm{Mn}, \mathrm{Zn}, \mathrm{Cu}$, and $\mathrm{Fe}$ in kernels (F5 generation) of winter triticale produced by crossbreeding three maternal with two paternal forms. As maternal forms, two strains were used, IGS 5101, FDT 975, as well as cultivar Alzo. The paternal components consisted of strains LAD 122 and F 8063. Morphologically established hybrid strains were selected at the Institute of Genetics, Plant Breeding and Biotechnology of the University of Life Sciences in Lublin. The component selection for crossbreeding was performed to achieve hybrids with great yield-forming potential and to improve the resistance to grain sprouting. Minerals were determined by the atomic absorption spectrometry (AAS) method. The results revealed differentiation in amounts of the analysed mineral components in hybrids depending on genotypes of the parental forms. Hybrid strains were usually characterized by a lower ash content in kernels than the parental forms. Among all the hybrids, strain IGS $5101 \times$ F 8063 was distinguishable by its higher content of $\mathrm{K}, \mathrm{Ca}, \mathrm{Mn}$, and $\mathrm{Fe}$ in grain versus both parental forms. It also excelled exceeded the other hybrids in respect of $\mathrm{Ca}, \mathrm{K}$ and $\mathrm{Mn}$. Tests on the mineral components in hybrid triticale strains indicate that it is possible to shape their levels through an appropriate selection of parental forms and selection during breeding work on $\mathrm{X}$ Triticosecale Wittmack genus to achieve cultivars of improved nutritional value.
\end{abstract}

Key words: triticale, hybrid strains, mineral elements.

prof. dr hab. Ewa Makarska, Chair of Chemistry, University of Live Sciences, Akademicka 15, 20-950 Lublin, Poland, phone: 08144565 86, e-mail: ewa.makarska@wp.pl 


\title{
WPŁYW FORM RODZICIELSKICH NA ZMIANY ZAWARTOŚCI SKŁADNIKÓW MINERALNYCH W ZIARNIE NOWYCH RODÓW MIESZAŃCOWYCH PSZENŻYTA OZIMEGO
}

\begin{abstract}
Abstrakt
W pracy badano zawartość $\mathrm{Ca}, \mathrm{Mg}, \mathrm{K}, \mathrm{Mn}, \mathrm{Zn}, \mathrm{Cu}, \mathrm{Fe}$ w ziarnie (pokolenie F5) pszenżyta ozimego otrzymanego $\mathrm{w}$ wyniku krzyżowania trzech form matecznych $\mathrm{z}$ dwoma ojcowskimi. Jako formy mateczne użyto: 2 rody IGS 5101, FDT 975 i odmianę Alzo. Formami ojcowskimi były rody LAD 122 i F 8063. Rody mieszańcowe ustalone morfologicznie wyselekcjonowano w Instytucie Genetyki, Hodowli Roślin i Biotechnologii Uniwersytetu Przyrodniczego w Lublinie. Dobór komponentów do krzyżowania prowadzono w celu uzyskania mieszańców o dużym potencjale cech plonotwórczych oraz poprawienia odporności na porastanie ziarna. Zawartość składników mineralnych analizowano metodą absorpcyjnej spektrometrii atomowej (AAS). Wyniki badań wykazały zróżnicowanie poziomu badanych składników mineralnych $\mathrm{w}$ mieszańcach zależnie od genotypów form rodzicielskich. Rody mieszańcowe wykazywały zwykle niższą popiołowość ziarniaków $\mathrm{w}$ porównaniu $\mathrm{z}$ formami rodzicielskimi. Z badanych mieszańców wyróżniał się ród IGS $5101 \times \mathrm{F} 8063$, w którego ziarnie stwierdzono wyższą zawartość $\mathrm{K}, \mathrm{Ca}, \mathrm{Zn}, \mathrm{Mn}$ i $\mathrm{Fe}$ w odniesieniu do obu form rodzicielskich oraz $\mathrm{Ca}, \mathrm{K}$ i $\mathrm{Zn}$ w porównaniu z pozostałymi rodami mieszańcowymi. Badania zawartości składników mineralnych $\mathrm{w}$ mieszańcowych rodach pszenżyta wskazuja na możliwość kształtowania ich poziomu przez odpowiedni dobór komponentów rodzicielskich i selekcję $\mathrm{w}$ pracach hodowlanych $\mathrm{w}$ obrębie rodzaju X Triticosecale Wittmack dla uzyskania odmian o wyższej wartości żywieniowej.
\end{abstract}

Key words: pszenżyto, rody mieszańcowe, składniki mineralne.

\section{INTRODUCTION}

Triticale is a cereal plant that has modest requirements and is tolerant to low soil pH and water deficiency (MASŁOWSKI et al. 1994, KACZMARCZYK et al. 2000). It can therefore be grown on lighter soils, under soil and weather conditions typical of Poland. When evaluated for its nutritional value as fodder, triticale demonstrates many advantages, for instance high protein levels of higher biological value than proteins in wheat or rye, richer mineral composition, and smaller amounts of anti-nutritive substances than rye (Makarska, Gruszecka 1998, Kociuba, Wasak 1998). Breeders continue to be interested in $\mathrm{r}$ achieving stable triticale genotypes, characterized by high potential and good quality of kernels. Thus, new sources of genetic material for creative breeding are searched for in order to obtain genotypes of greater practical importance and potential, also as a baking grain, than the initial forms (GUSTAFson et al. 1989, GRUSZECKA et al. 2004, MAKARSKA 2000, SODKIEWICZ et al. 2002). Valuable forms can be obtained by introducing into crossbreeding components which supply genes that make plants resistant to diseases, tolerant to drought or high temperatures, or adaptable to be cultivated under different $\mathrm{pH}$ conditions (MASŁOWSKI et al. 1994). 
There is growing interest in the breeding work in which where related wild forms (Aegilops sp. or Agrotriticum) are used for crossbreeding with triticale. Beside improving the resistance to environmental factors, the obtained material is expected to have wider genetic diversity in terms of chemical composition, including mineral make-up (MAKARSKA, GruszeCKA 1996, 2000).

The study aimed at evaluating the content of nutrients in grains of hybrid triticale strains as compared to their parental forms.

\section{MATERIAL AND METHODS}

The material for study consisted of kernels of 5 hybrid winter triticale strains produced by crossbreeding strains and varieties originating from various collections as well as their parental forms (F5 generation) - Table 1 . The hybrids were morphologically established and selected at the Institute of Genetics, Plant Breeding and Biotechnology of the University of Live Sciences in Lublin. The grain samples were taken from a field experiment set in 2 replications on $2 \mathrm{~m}^{2}$ area plots on loess soil with brown subsoil. Common vetch was the forecrop. Mineral fertilization was applied at the following amounts: $60 \mathrm{~kg} \mathrm{~N} \mathrm{ha}^{-1}, 80 \mathrm{~kg} \mathrm{ha}^{-1} \mathrm{P}_{2} \mathrm{O}_{5}, 100 \mathrm{~kg} \mathrm{ha}^{-1} \mathrm{~K}_{2} \mathrm{O}$.

Table 1

\begin{tabular}{|c|c|c|}
\multicolumn{3}{|c}{ Material for study } \\
\hline Sample number & Forms & Strain / Cultivar \\
\hline 1 & & IGS 5101 \\
2 & maternal form & FDT 975 \\
3 & & Alzo \\
\hline 4 & paternal form & LAD 122 \\
5 & & F 8063 \\
\hline 6 & & IGS 5101 $\times$ LAD 122 \\
7 & & IGS 5101 $\times$ F 8063 \\
8 & hybrid strain & Alzo $\times$ LAD 122 \\
9 & & Alzo $\times$ F 8063 \\
\hline
\end{tabular}

The component selection for crossbreeding was performed to obtain hybrids of great yield-forming potential and to improve the resistance to grain sprouting. Since the qualitative traits of the hybrids had not been previous- 
ly tested, such an analysis was performed. Qualitative determinations of early uniform populations of strains facilitate their proper selection for further breeding and may be a starting point for establishment of a new variety.

Minerals $(\mathrm{Ca}, \mathrm{Mg}, \mathrm{K}, \mathrm{Fe}, \mathrm{Mn}, \mathrm{Zn}, \mathrm{Cu})$ were determined by the atomic absorption spectrometry (AAS) method using a UNICAM 939 apparatus after combustion in a muffle furnace and dissolution in hydrochloric acid (1:1). All the analysis were made in three replications. The results were statistically processed by calculating arithmetic means, while the verification of differences between mean values for particular hybrid strains and parental components was performed with variance analysis and Tukey's test at the level of significance $p=0.05$. The coefficient of variation was calculated according to the formula: (standard deviation/arithmetic mean) $\cdot 100 \%$.

\section{RESULTS AND DISCUSSION}

The hybrids, as compared to the parental forms, were usually characterized by a lower ash content, except strain IGS $5101 \times \mathrm{F} 8063$, which had the highest ash content in grain (1.98\%) - Table 2 . The analysis of the content of macronutrients and microelements in hybrid kernels and their parental forms showed variability of levels of these elements. The study focused on the influence of a genotype on the content of mineral nutrients in order to confirm the possibility of shaping their levels in hybrid strains through a proper selection of parental forms.

Beside the genotype effect, other authors (Feil, Fossati 1995) pointed to a significant effect of the field location and year on the uptake and accumulation of minerals in cereal grains. Such influence was determined for most of mineral elements, whose level was also affected by the interaction between location and weather conditions.

When evaluating the content of macronutrients in winter triticale, it was found that $\mathrm{Ca}$ concentration in kernels of the maternal form cv. Alzo was significantly higher than in the other maternal components. Among the analyzed paternal forms, kernels of LAD 122 strain were characterized by a higher $\mathrm{Ca}$ level, although the paternal components did not statistically differ. The level of $\mathrm{Ca}$ in hybrid strains - IGS 5101 x LAD 122 and FDT $975 \times$ LAD 122 - was lower than in the parental kernels; they were a homogenous group with the maternal forms but had a significantly lower $\mathrm{Ca}$ content than the paternal components. For the strains Alzo x LAD 122 and Alzo x F 8063, the Ca content in grain was moderate; statistically it was a homogenous group with both parental forms. In the strain IGS $975 \mathrm{x}$ F 8063, the Ca concentration in grain was considerably higher than in both parental forms (Table 2). 


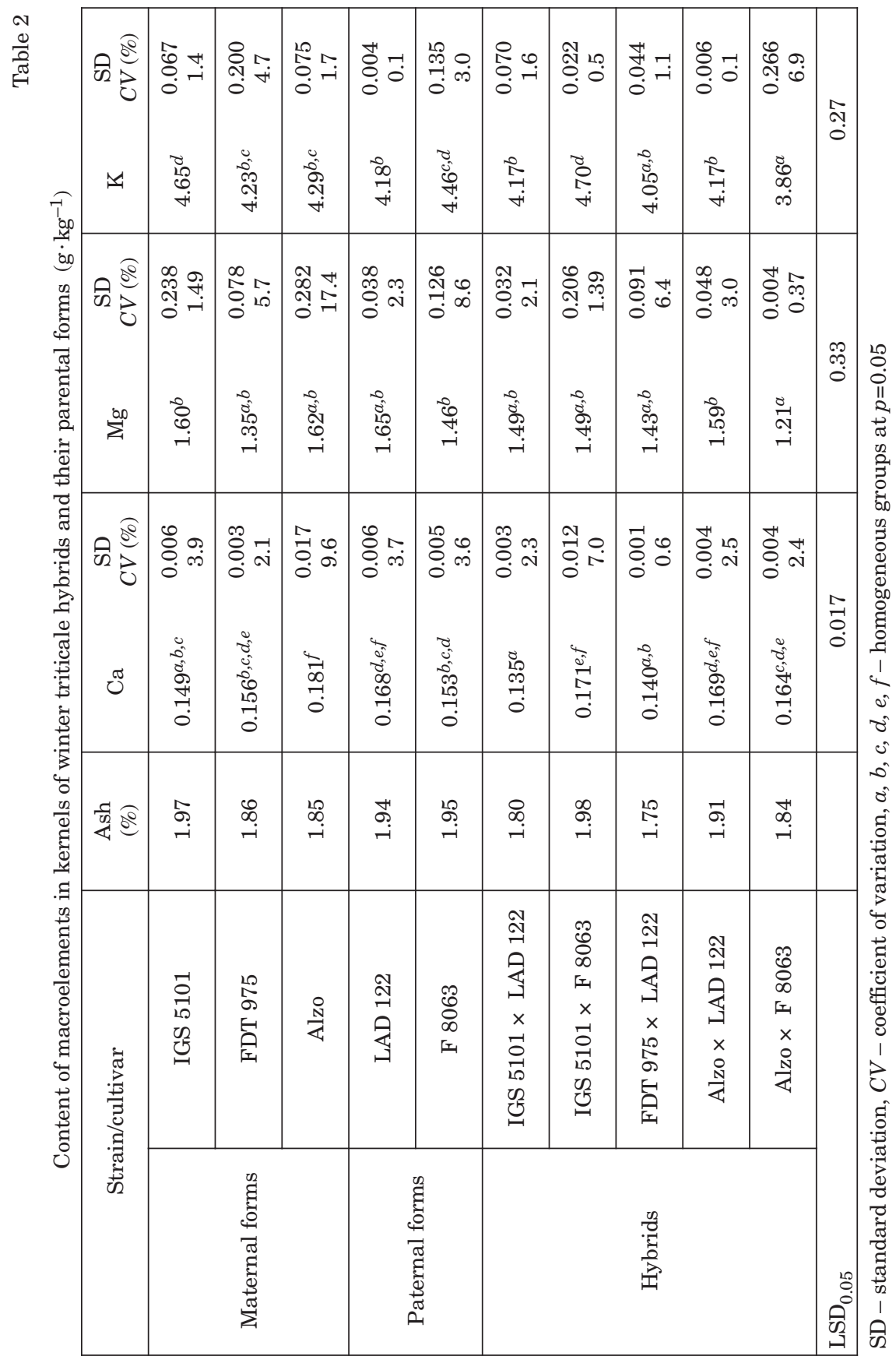


No significant differences in $\mathrm{Mg}$ were found between the parental forms. The content of $\mathrm{Mg}$ in kernels of three hybrids, i.e. IGS $5101 \times$ LAD 122, Alzo x LAD 122 and Alzo x F 8063, was lower than in the parental components. The latter strain contained significantly less magnesium than the paternal form F 8063, whereas the other differences were not significant. For the hybrid strains IGS $5101 \times$ F 8063 and FDT 975 x LAD 122, the Mg content in grain reached moderate values as compared to the parents (Table 2).

The maternal form IGS 5101 was distinguishable by its considerably higher potassium content than the other maternal components, in which it was similar to the paternal form F 8063. The hybrid strain IGS $5101 \times$ F 8063 derived from these parental components was characterized by a significantly higher $\mathrm{K}$ concentration than the other hybrids. Furthermore, it was the only hybrid that contained more $\mathrm{K}$ than its both parents. The other hybrid strains, as compared to the corresponding parental forms, were characterized by lower potassium levels. In the case of Alzo x F 8063 strain, the difference was statistically significant versus both parental forms (Table 2).

The effect of different factors (e.g. fertilization) on content of macronutrients in triticale grain was analyzed by others authors. Higher nitrogen rates contributed to an increase in the potassium concentration (PILEJCZYK et al. 2004) and nitrogen magnesium fertilisation had a positive effect on the accumulation of potassium, magnesium and sodium in triticale grain (WYszKOWSKI 2001).

Levels of microelements ( $\mathrm{Fe}, \mathrm{Mn}, \mathrm{Cu}, \mathrm{Zn})$ in the analysed hybrid strains were diversified and depended on the parental forms (Table 3). The content of $\mathrm{Fe}$ and $\mathrm{Mn}$ in the hybrids was evidently affected by the strain LAD 122 (paternal form), which was distinguishable by the highest levels of these elements among grain samples. All the hybrids originating from this form (i.e. IGS $5101 \times$ LAD 122, FDT 975 x LAD 122, and Alzo x LAD 122) contained significantly less manganese than the paternal strain and more than the maternal forms, although these differences were not significant. And similarly, a moderate content of $\mathrm{Fe}$ in the hybrid strains, relative to the parental forms, was not statistically significant at $p=5 \%$. The content of $\mathrm{Fe}$ and Mn was significantly lower in the hybrid strain Alzo x F 8063. Kernels of this strain contained less of these elements than the maternal and paternal forms (Table 3).

A considerably higher content of copper versus the other maternal forms was found in IGS 5101, in which it was similar to the paternal form LAD 122. The hybrid strain IGS $5101 \times$ LAD 122 also contained a significantly higher $\mathrm{Cu}$ level as compared to the other hybrids. The content of $\mathrm{Cu}$ in kernels of four hybrid strains IGS 5101 x LAD 122, FDT 975 x LAD 122, Alzo x F 8063, and IGS 5101 x F 8063 was lower than in both parental forms. In the case of the hybrid strains IGS 5101 x LAD 122 and Alzo x F 8063, the difference was considerable as compared to the parental components; 


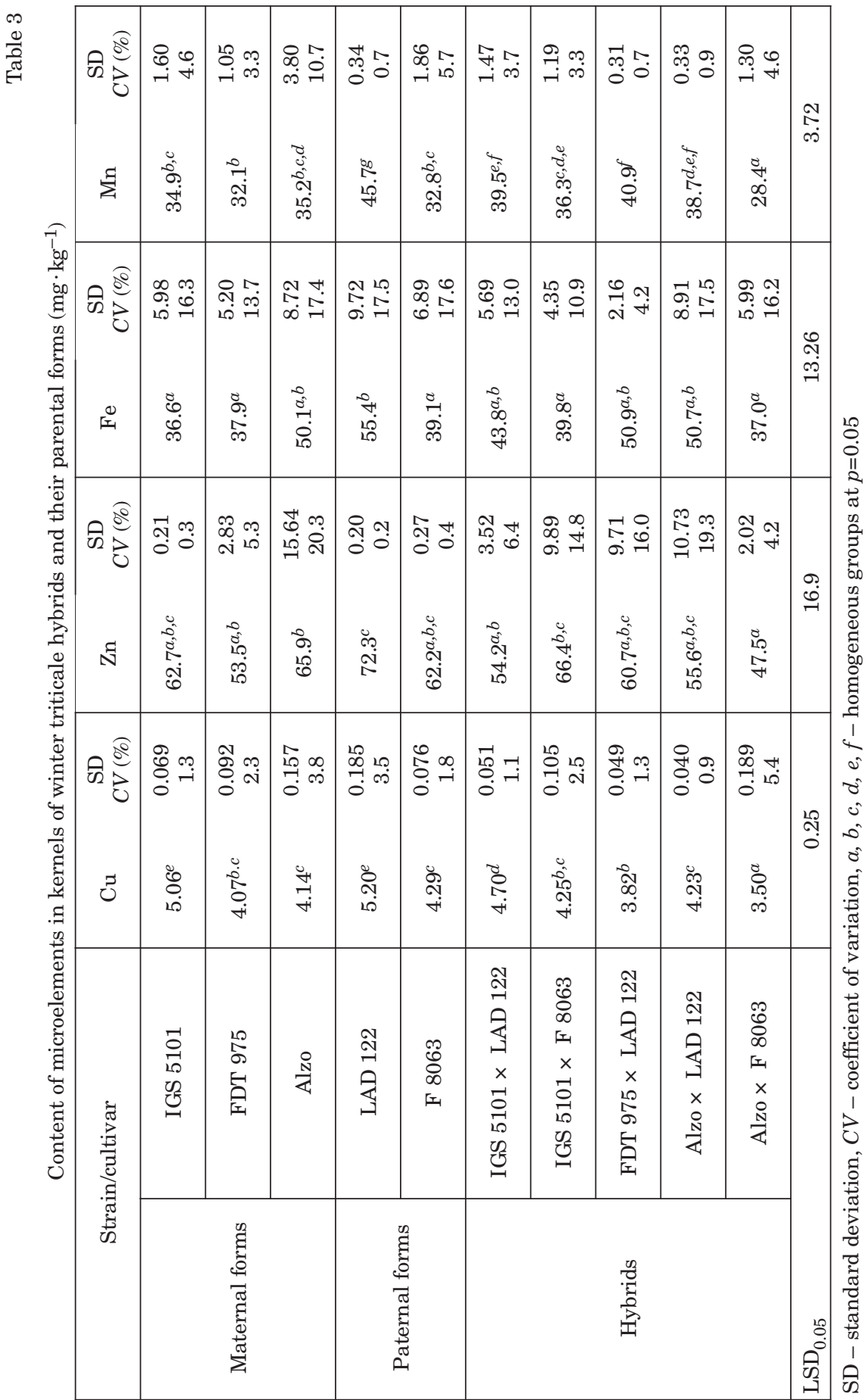


the FDT 975 x LAD 122 hybrid contained significantly less $\mathrm{Cu}$ than its paternal form, and IGS 5101 x F 8063 - than its maternal form (Table 3). Our comparison of the hybrids IGS $5101 \times$ LAD 122, FDT $975 \times$ LAD 122 and Alzo x LAD 122 originating from the same paternal form showed an evident influence of the maternal component on the $\mathrm{Cu}$ level in kernels of the hybrid strains.

The level of $\mathrm{Zn}$ in the hybrids was the most advantageous in the strain IGS 5101 x F 8063, in which it significantly exceeded both parental forms (Table 3). Considerably less zinc was found in kernels of the hybrids IGS 5101 x LAD 122, Alzo x LAD 122 and Alzo x F 8063 when compared to parental components.

The content of the determined mineral components in triticale strains was compared to the levels found in triticale by SoucI et al. (2000). The concentrations of $\mathrm{Ca}$ and $\mathrm{Cu}$ in the strains analyzed in our research were below the average values reported by the above authors. The zinc content was twice as high, while the iron level was similar to the values found by SoucI et al. 2000.

When comparing the mean values of macronutrients and microelements in kernels of the analyzed strains with the results presented by VARUGHESE et al. (1996) for many triticale varieties, higher levels of $\mathrm{Mg}, \mathrm{Ca}, \mathrm{Zn}$, and Mn but a similar content of $\mathrm{Cu}$ were observed.

When comparing the average content of minerals in grain of the analyzed strains with 14 promising strains cultivated in India, their differentiation depending on the genotype features can be seen (SeHGAL et al.1983). Our analysis of the mean levels of minerals for all the objects revealed that the analyzed strains were characterized by a higher content of $\mathrm{Mn}$ and $\mathrm{Zn}$ in grain, similar $\mathrm{K}$ level and lower concentrations of $\mathrm{Ca}, \mathrm{Cu}$, and $\mathrm{Fe}$ than the mentioned strains from India (SeHgal et al. 1983). Similarly to other studies (SEHGAL et al. 1983), the grain of the strains we tested demonstrated positive correlations between the ash content and concentrations of $\mathrm{K}$ and Mn. Considering solely the genetic variability, FeIL and Fossati (1995) proved positive correlation between protein and mineral levels. When comparing the protein content in kernels of the analyzed strains (previously published data, MAKARSKA et al. 2008), positive correlation of this parameter with the content of minerals was determined in the hybrid strains. The hybrid strain Alzo x LAD 122 with the highest protein content was also characterized by the highest $\mathrm{Zn}, \mathrm{Fe}, \mathrm{Mn}$, and $\mathrm{Cu}$ concentrations in grain. 


\section{CONCLUSIONS}

1. Triticale hybrid strains, as compared to their parental forms, were usually characterized by a lower ash content in kernels, except the strain IGS 5101 x F 8063.

2. The IGS 5101 x F 8063 hybrid strain excelled both parental forms in terms of $\mathrm{Ca}, \mathrm{K}, \mathrm{Zn}, \mathrm{Fe}, \mathrm{Mn}$ levels; it was also distinguishable from the other hybrids by higher $\mathrm{Ca}, \mathrm{K}$ and $\mathrm{Mn}$ levels.

3 . The differentiation of mineral components in the hybrid strains depended on the selection of parental forms.

4. Tests on the mineral components in triticale strains suggest that it is possible to shape their levels through a proper selection of parental components and selection, which takes into account the positive features within $\mathrm{X}$ Triticosecale Wittmack genus.

\section{REFERENCES}

Feil B., Fossati D. 1995. Mineral Composition of Triticale Grains as Related to Grain Yield and Grain Protein. Crop Sci., 35: 1426-1431

Gruszecka D., Kulpa D., Makarska E. 2004. Evalution of grain technological quality of $X$ Triticosecale Wittmack with Aegilops sp.hybrids. Int. Agrophysics, 18: 127-132.

Gustafson J.P., Dille J. E., Skovmand B. 1989. Wheat substitution in hexaploid triticale. Plant Breed., 102: 109-112.

Kaczmarczyk S., Koszański Z., PodsiadŁo C. 2000. Reakcja pszenżyta jarego na deszczowanie i nawożenie mineralne [Response of spring triticale to sprinkling and mineral fertilization]. Cz. I. Fol. Univ. Agric. Stetin. 206, Agricult., 82: 109-116 (in Polish).

Kociuba W., WaSAK E. 1998. Zawartość biatka $w$ ziarniakach form korekcyjnych pszenżyta (X Triticosecale Wittmack) [Content of protein in kernels of correction forms of triticale ((X Triticosecale Wittmack). Biul. IHR 226/ 227(1): 43-46 (in Polish).

Makarska E., Gruszecka D. 1996. Wptyw komponentów rodzicielskich na zawartość mikro i makroelementów mieszańcowych ziarniaków pszenżyta $z$ pszenperzem. Cz. I. [Effect of parental components on content of micro- and macroelements in kernels of hybrids of triticale with wheat grass. Part I]. Zesz. Probl. Post. Nauk Rol., 434: 105-109 (in Polish).

MakarsKa E., Gruszecka D. 1998. Antytrypsin activity and level of alkylresorcinols in hybrid kernels of X Triticosecale Wittmack with Agrotriticum and in parental form. Pol. J. Food Nutr. Sci., 7/48 (3): 431-434.

MaKaRsKa E., GRUSZECKa D. 2000. Wptyw pszenżytnich form rodzicielskich na zawartość mineralnych sktadników pokarmowych $w$ mieszańcowych ziarniakach $X$ Triticosecale Wittmack $z$ Aegilops sp. [Effect of triticale parental forms om content of mineral nutrients in kernels of hybrids of X Triticosecale Wittmack with Aegilops sp.]. Biul. Magnezol., 5(3):171-176 (in Polish).

MAKARSKA E. 2000. The attempt to connect the glutenin composition with evaluation of the banking quality of winter triticale grain. Pol. J. Food Nutr. Sci., 9/50(2): 21-24.

Makarska E., CioŁer A., Kociuba W. 2008. Composition of gluten proteins and quality parameters of winter triticale hybrids. Pol. J. Food Nutr. Sci., 58 (3): 341-344. 
MasŁowski J., Gruszecka D., TARKowski Cz. 1994. Tolerancyjność różnych genotypów pszenżyta na stresowe dziatanie jonów glinu [Tolerance of different triticale genotypes to stress effect of aluminium ions]. Zesz. Nauk. AR w Szczecinie, 162, Rol., 63: 147-149 (in Polish).

Pilejczyk D., Sienkiewicz S., Wojnowska T., Żarczyński P. 2004. Wptyw gęstości siewu i nawożenia azotem na zawartość makrosktadników $w$ ziarnie pszenżyta jarego [Effect of sowing density and nitrogen fertilization on content of macronutrients in grain of spring triticale]. J. Elementol., 9 (1): 35-45 (in Polish).

Sehgal K.L., BajAJ S., Sekhon K.S. 1983. Studies on the composition, quality and processing of triticale. Part II. Mineral composition of grain and flour. Nahrung., 27: 39-44.

Sodkiewicz W., Sodkiewicz T., Makarska E. 2002. Introgression of Triticum monococcum Genes as a Metod of Widening of Hexaploid Triticale Biodiversity. Cereal Section Meeting. Eucarpia., 147-149.

Souci S., Fachmann W., Kraut H. 2000. Food composition and Nutrion Tables. Scientific Publishers, Stuttgart.

Varughese G., Pfeiffer W.H. Pena R.J. 1996. Triticale: a successful alternative crops (part 1). Cereal Foods Word, 41 (6): 474-482.

WyszKowski M. 2001. Zmiany pobrania makroskładników przez pszenżyto jare $w$ zależności od nawożenia mineralnego [Changes in uptake of macronutrients by spring triticale depending on mineral fertilization]. J. Elementol., 6 (4): 700-708 (in Polish). 